\title{
REAKSI PASAR ATAS PENGUMUMAN DIVIDEN \\ (STUDI PADA EMITEN YANG TERDAFTAR DI JAKARTA ISLAMIC INDEX)'
}

\author{
Ari Widodo \\ Program Studi S1 Ekonomi Islam-Fakultas Ekonomi dan Bisnis-Universitas Airlangga \\ Email: 31 ariwid@gmail.com \\ Nisful Laila \\ Departemen Ekonomi Syariah-Fakultas Ekonomi dan Bisnis-Universitas Airlangga \\ Email: nisful.laila@gmail.com
}

\begin{abstract}
:
This research aims to see market reaction over the increasing and declining dividend announcement. The objective in this research is to test whether the stock price reacts positively to the increasing dividend announcement and reacts negatively to the declining dividend announcement are shown by the significant abnormal return (AR) value in around the announcement date and by the significant difference of abnormal trading volume activity (ATVA) before and after the announcement. The results indicate that market does not react over increasing as well as decreasing dividend announcement. This indicates that the event of dividend changes announcement are not reacted by market.

Keywords: increasing dividend, declining dividend, abnormal return, abnormal trading volume activity
\end{abstract}

\section{PENDAHULUAN}

Sebagai Muslim, tentunya instrumen investasi yang dipilih adalah yang halal yaitu sesuai prinsip syariat Islam dan bebas dari maysir, gharar, riba, dhalim, juga haram. Salah satu instrumen investasi populer yang dapat menjadi pilihan adalah investasi pada pasar modal.

Pada ayat Al-Qur'an surat Al-Baqarah 261, diumpamakan orang yang menafkahkan atau berinfestasi pada ladang bisnis yang halal diumpamakan penyertaanya sebagai bulir pada yang terus tumbuh menjadi banyak dan berlipat ganda. Ayat di tersebut menggambarkan bagaimana layaknya investasi pada pasar modal. Apabila investor benar melakukan dan selektif, maka hasil akan diperoleh dari penyertaannya.

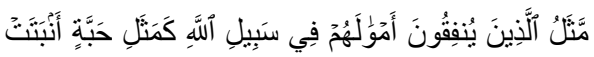

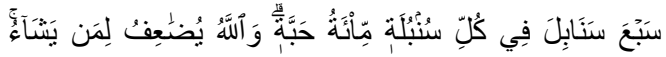

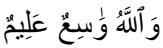
dikeluarkan oleh) orang-orang yang menafkahkan hartanya di jalan Allah adalah serupa dengan sebutir benih yang menumbuhkan tujuh bulir, pada tiap-tiap bulir seratus biji. Allah melipat gandakan (ganjaran) bagi siapa yang Dia kehendaki. dan Allah Maha Luas (karuniaNya) lagi Maha mengetahui".

Sejak diterbitkannya Jakarta Islamic Index (JII) oleh Bursa Efek Indonesia (BEI) bekerjasama dengan PT Danareksa Investment Management pada 3 Juli 2000, Para investor muslim lebih mudah untuk melakukan investasi pada saham yang berbasis syariah yaitu emiten yang kegiatan usaha maupun operasional

\footnotetext{
1) Jurnal ini merupakan bagian dari skripsi yang ditulis oleh (Ari Widodo; 041 114074)
} 
emiten tidak bertentangan dengan syariah. Jakarta Islamic Index juga dijadikan sebagai indikator kinerja saham syariah di Indonesia. Indeks ini merupakan daftar efek emiten yang terdiri dari 30 saham syariah paling likuid dan berkapitalisasi besar. Untuk menjaga nilai syariah pada emiten-emiten terdaftar di JII di-review setiap enam bulan sekali oleh BEI sehingga akan ada pembaharuan daftar emiten yang masuk maupun keluar JII setiap enam bulan sekali. Pada prakteknya, fungsi-fungsi pasar modal Islam bersifat parallel dengan pasar modal konvensional dalam memediasi pencari dan penyedia dana (Dariyus, 2012:4).

Alasan umum mengapa para investor memilih instrumen investasi pasar modal adalah dividen (yield) dan capital gain. Investor berharap mendapatkan dividen sebagai bagi hasil keuntungan atas penyertaannya berupa saham yang dibelinya sebagai representasi kepemilikan modal terhadap perusahaan, seperti kalanya bertransaksi dengan akad mudharabah. Dalam Al-Quran surat AnNisa Allah telah menjelaskan jaln mencari nafkah melalui perniagaan.

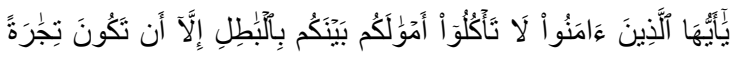

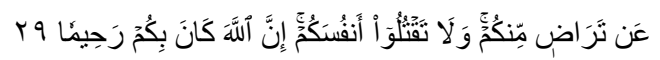
Artinya: "Hai orang-orang yang beriman, janganlah kamu saling memakan harta sesamamu dengan jalan yang batil, kecuali dengan jalan perniagaan yang Berlaku dengan suka sama-suka di antara kamu. dan janganlah kamu membunuh dirimu; Sesungguhnya Allah adalah Maha Penyayang kepadamu".

Disamping itu, ada capital gain yang merupakan selisih (margin) antara harga jual dan harga beli yang didapat ketika saham dijual. Capital gain dianggap lebih menjanjikan karena cenderung naik berdasarkan nilai perusahaannya.

Layaknya suatu pasar, bursa efek syariah akan cepat sekali menyerap suatu informasi maupun kabar yang akan mempengaruhi produk jualan yang ditransaksikan pada pasar tersebut dengan cerminan harga produk tersebut. Pada lantai bursa, kebijakan-kebijakan maupun pengumuman yang menyebabkan perubahan harga saham seperti pengumuman dividen misalnya, merupakan hal yang menarik untuk dicermati oleh para investor karena bisa jadi akan berpengaruh terhadap harga saham ditransaksikan. Harga saham yang naik, akan berbanding lurus dengan capital gain yang akan diperoleh. Foster (1986:377) dalam Hartono (2013:551) menjelaskan bahwa pengumuman pembagian dividen merupakan salah hal yang dapat mempengaruhi harga saham.

$$
\text { Aharony dan Swary (1980) dalam }
$$
Mirdah dan Solikin (2010:1) mengemukakan bahwa dua isyarat paling penting yang tersedia dari perusahaan yaitu pengumuman dividen dan laporan keuangan. Kedua isyarat tersebut digunakan oleh perusahaan untuk menyampaikan informasi penting mengenai arus kas dan nilai perusahaan 
di masa depan kepada publik ketika terjadi asimetri informasi. Berdasarkan dividend signaling theory yang dikemukakan oleh Bhattacharya (1979), informasi yang terkandung dalam pengumuman dividen sangat berarti bagi investor sehingga dapat mempengaruhi return saham. Model tersebut digunakan untuk menjelaskan mengapa perusahaanperusahaan menggunakan dividend untuk memberi sinyal kepada investornya. Pengumuman dividen dianggap mempunyai kandungan informasi dan dapat digunakan oleh investor sebagai sinyal tentang prospek perusahaan. Menurut teori ini pengumuman dividen mengandung informasi tentang laba saat ini dan prospek perusahaan di masa depan, semisal kenaikan dividen.

Dividend Signalling Theory dalam Ross, et al. (2008:603) menyatakan bahwa keenaikan dividen dipandang sebagai berita baik (good news) dan sebaliknya penurunan dividen dipandang sebagai berita buruk (bad news). Suatu good news dan bad news ini tentunya akan direaksi masing-masing berbeda oleh pasar.

Pengumuman dividen meningkat yang dianggap sebagai suatu informasi baik atau good news memberikan arti bahwa suatu perusahaan tersebut memiliki prospek yang baik dan tingkat likuiditas yang baik. Pembagian dividen merupakan suatu tindakan yang membutuhkan biaya tinggi, sehingga tidak semua perusahaan mampu melakukannya. Adanya kepercayaan dari perusahaan mengenai prospek perusahaannya yang baik inilah maka pasar cenderung bereaksi positif. Reaksi pasar yang positif tercermin dari adanya abnormal return yang positif disekitar tanggal pengumuman pembagian dividen yang meningkat serta terjadi perubahan volume perdagangan positif yang terjadi sekitar tanggal pengumuman pembagian dividen meningkat. Hal ini telah dibuktikan oleh penelitian yang dilakukan oleh Zainafree (2005), Serang (2009) dan Mulyati (2003). Sedangkan, pengumuman dividen menurun yang dianggap sebagai suatu bad news oleh pasar, tentunya akan direaksi negatif oleh pasar. Pasar menganggap perusahaan tersebut memiliki prospek perusahaan yang kurang baik serta dianggap memiliki kesulitan likuiditas sehingga harus menurunkan jumlah dividen yang akan dibayarkan kepada pemegang saham agar mampu tetap membagikan dividen dan juga tidak mengganggu kas perusahaan. Reaksi pasar negatif tercermin dari adanya abnormal retun negatif dan perubahan volume perdagangan negatif. Hal ini telah dibuktikan oleh penelitian yang dilakukan oleh Mulyati (2003), Mederios and Matsumoto (2006) dalam Wahyuni dan Sukartha (2012). Penelitian yang menunjukkan bahwa pengumuman dividen tidak memiliki kandungan informasi ditemukan pada penelitian Mulyono (2001), Nawawi (2012) dan Agriani (2011). 
Widodo, et al/Jurnal Ekonomi Syariah Teori dan Terapan Vol. 3 No. 2 Februari 2016: 85-98; REAKSI PASAR ATAS PENGUMUMAN DIVIDEN (STUDI PADA EMITEN YANG TERDAFTAR DI JAKARTA ISLAMIC INDEX)

Berdasarkan perbedaan hasil penelitian di atas dan keingintahuan penulis mengenai kelurusan kejadian dengan teori dan sudut pandang syariah, maka dilakukan penelitian dengan subyek dan waktu yang. Pada penelitian ini, peneliti memakai teknik analisis studi peristiwa (event study) karena dapat mengetahui kandungan informasi dari suatu pengumuman dividend dan dapat juga menguji hipotesis pasar efisien setengah kuat. Tahun 2014 dipilih sebagai tahun terbarukan dari penulisan penelitian ini dan ketersediaan akan data yang dibutuhkan dalam penulisan.

\section{LANDASAN TEORI}

Fama (1965 dan 1970) dalam Krichene (2013: 139) mendefinisikan pasar yang efisien sebagai pasar yang harga di dalamnya selalu mencerminkan informasi yang tersedia. Dalam teori pasar efisien, pasar terdiri atas pasar efisien bentuk kuat, setengah kuat, dan lemah. Penelitian ini termasuk dalam pengujian bentuk pasar efisien setengah kuat, yaitu pasar dimana harga-harga sekuritas secara penuh mencerminkan (fully reflect) semua informasi yang dipublikasikan (all publicly available information) termasuk informasi yang berada di laporan-laporan keuangan perusahaan emiten. Dalam penelitian ini, informasi yang dipublikasikan tersebut adalah pengumuman dividen.

Dalam prespektif Islam, Obaidullah (2007:23) menjelaskan bahwa ada empat bentuk efisiensi yaitu:
1. Efisiensi alokasi (allocational efficiency), menyatakan bahwa dana investasi dihubungkan dengan aset yang berharga

2. Efisiensi harga (pricing efficiency), merupakan prasyarat untuk efisiensi alokasi yang berarti harga dari suatu saham harus sebanding dengan masingmasing nilai fundamental emiten sepanjang waktu.

3. Efisiensi informasi (informational efficiency), menyatakan bahwa tidak ada katerlambatan (lags) pada persebaran dan penyerapan informasi dan itu adalah prasarat dari efisiensi harga.

4. Efisiensi operasional (operational efficiency), yang menyatakan bahwa niaya transaksi harus diambil untuk biaya yang paling minim.

Dari keempat bentuk diatas, dapat diketahui bahwa pemotongan biaya transaksi, penyederhanaan sistem transaksi, ketersediaan and akuransi informasi, perbaikan proses penyampaian informasi (signalling) agar terjadi efisiensi

Pasar efisien setengah kuat diuji dengan menggunakan event study, yaitu studi yang mempelajari reaksi pasar terhadap suatu peristiwa (event) yang informasinya dipublikasikan sebagai pengumuman (Hartono, 2013:585). Reaksi pasar merupakan respons pasar terhadap suatu peristiwa yang mengandung informasi ekonomi. Reaksi pasar tercermin pada adanya abnormal return di sekitar tanggal publikasi peristiwa dan adanya perbedaan trading volume activity 
Widodo, et al/Jurnal Ekonomi Syariah Teori dan Terapan Vol. 3 No. 2 Februari 2016: 85-98; REAKSI PASAR ATAS PENGUMUMAN DIVIDEN (STUDI PADA EMITEN YANG TERDAFTAR DI JAKARTA ISLAMIC INDEX)

sebelum dan sesudah tanggal publikasi peristiwa.

\section{METODE PENELITIAN}

Teknik analisis yang digunakan pada penelitian ini ialah event analysis. Hartono (2013:585) menyatakan bahwa studi peristiwa (event study) merupakan studi yang mempelajari reaksi pasar terhadap suatu peristiwa (event) yang informasinya dipublikasikan sebagai suatu pengumuman. Selanjutnya, Hartono menyatakan bahwa jenis penelitian ini dapat digunakan untuk menguji kandungan informasi (information content) dari suatu pengumuman dan dapat juga digunakan untuk menguji efisiensi pasar bentuk setengah kuat

Variabel-variabel yang diteliti berdasarkan rumusan masalah dan hipotesis antara lain:

a. Peristiwa (event) pengumuman dividen pada masing-masing emiten terdaftar di Jll selama tahun 2014

b. Average Abnormal Return (AAR),

c. Abnormal Trading Volume Activity (ATVA)

Sampel pada penelitian ini diambil dengan metode purposive sampling yaitu cara pengambilan sampel dengan pemilihan sampel yang memenuhi kriteriakriteria tertentu yang dikehendaki peneliti saja. Kriteria yang dikehendaki peneliti antara lain:

a. Perusahaan yang melakukan pengumuman dividen pada tahun 2014 b. Perusahaan terdaftar pada Jakarta Islamic Index (JII) pada saat melakukan pengumuman dividen baik pada periode Februari 2014 - Juli 2014 maupun Agustus 2014 - Januari 2015.

c. Emiten tidak melakukan melakukan aksi korporasi lain yang memungkinkan terjadi reaksi pasar seperti pemecahan (stock split), penerbitan saham perdana (initial public offering), informasi akuntansi, serta kebijakan perusahaan lain yang memiliki kandungan informasi yang kemungkinan mempengaruhi keputusan investasi investor.

d. Emiten melakukan pengumuman pembagian dividen yang menurun maupun meningkat.

\section{Definisi Operasional}

Dfinisi dari variabel-variabel yang digunakan dalam penelitian ini adalah:

Peristiwa (event) pengumuman dividen, merupakan tanggal RUPS di mana emiten mengumumkan pembagian dividen untuk investor.

\section{Rata-rata abnormal return (AAR) Average}

abnormal return merupakan rata-rata abnormal return yang sedang dianalisis. Average Abnormal Return dihitung menggunakan rumus:

$\mathrm{AAR}_{+}=\frac{\sum A R t}{n}$

AARt : rata-rata abnormal return pada periode ke- $\dagger$

ARt : abnormal return saham emiten pada periode peristiwa ke- $\dagger$ 
$n$ : jumlah sampel/jumlah emiten yang diamati.

\section{Abnormal Trading Volume Activity (ATVA)}

adalah abnormal volume perdagangan saham oleh investor yang digunakan untuk melihat adanya reaksi pasar modal atau perubahan harga saham terhadap informasi yang dipublikasikan. ATVA dapat dihitung dengan menggunakan rumus sebagai berikut:

ATVA $_{t}=$ Actual TVAt - expected TVA $t$

ATVA $_{t} \quad$ : volume perdagangan abnormal yang terjadi di periode ke- $\dagger$

Actual TVA $A_{t}$ : volume perdagangan yang terjadi pada hari ke-†

Expected TVA $A_{t}$ : volume perdagangan yang diharapkan pada hari ke- $\uparrow$

Prosedur Pengumpulan Data

Tahapan-tahapan yang dilakukan dalam penelitian ini antara lain:

1. Tahap pertama dilakukan studi kepustakaan dengan mengumpulkan teori-teori pendukung dari literatur dan penelitian-penelitian terdahulu guna mendapatkan literasi mengenai kajian teori sebagai alternatif pemecahan masalah yang menjadi bahasan dalam penelitian ini.

2. Tahap kedua adalah mencari datadata sekunder yang diperlukan dalam penelitian ini, antara lain:

a. Daftar perusahaan terdaftar pada Jakarta Islamic Index (JII) selama tahun 2014 baik pada periode Pebruari- Juli 2014 maupun Agustus 2014 - Januari 2015 yang melakukan pengumuman dividen.

b. Tanggal perusahaan yang terdaftar pada Jakarta Islamic Index (JII) saat melakukan pengumuman dividen selama tahun 2014.

c. Data mengenai harga penutupan dan volume transaksi saham emiten terdaftar pada Jakarta Islamic Index (JII) yang melakukan dividen selama tahun 2014.

\section{Teknik Analisis Data}

Teknik analisis data yang digunakan pada penelitian ini adalah studi peristiwa atau event study. Hartono (2013: 586) memaparkan studi peristiwa (event study) merupakan studi yang mempelajari reaksi pasar terhadap suatu peristiwa (event) yang informasinya dipublikasikan sebagai suatu pengumuman. Event study dapat digunakan untuk menguji suatu kandungan suatu informasi (information content) dari suatu pengumuman dan dapat juga digunkan untuk menguji efisiensi pasar setengah kuat. Suatu peristiwa yang memiliki kandungan informasi akan menyebabkan pasar bereaksi. Adapun periode uji dalam penelitian ini adalah 21 hari periode pengamatan (event windows) yang terdiri atas 10 hari sebelum peristiwa (t-10), hari peristiwa (t0), serta 10 hari setelah peristiwa $(t+10)$ pengumuman dividen oleh emiten. Model yang digunakan 
adalah market adjusted model (model sesuaian pasar), dengan menggunakan model ini, maka tidak perlu menggunakan periode estimasi untuk membentuk model estimasi karena return saham yang diestimasi adalah sama dengan return indeks pasar. Penelitian ini mengamati perubahan harga saham yang ditunjukkan dengan adanya abnormal return di sekitar tanggal pengumuman dividen dan perbedaan tingkat trading volume activity (TVA) sebelum dan sesudah pengumuman dividen pada emiten.

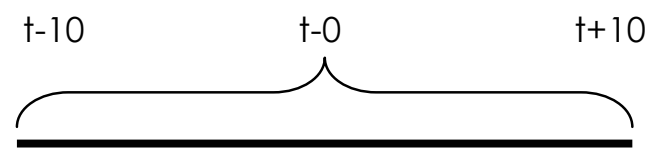

Gambar 1

Periode Pengamatan

Langkah-langkah dalam teknis analisis data adalah sebagai berikut:

1. Menghitung actual return saham individual (Rit) selama waktu pengamatan dengan menggunakan rumus:

$$
R_{i, t}=\left[\frac{P_{i, t}-P_{i, t-1}}{P_{i, t-1}}\right]
$$

Keterangan:

Ri, $\uparrow=$ Return aktual saham i periode $\dagger$

$\mathrm{Pi}, \dagger=$ harga saham $\mathrm{i}$ periode $\dagger$

$\mathrm{Pi}, \mathrm{t}-1=$ harga saham $\mathrm{i}$ periode $\mathrm{t}-1$

2. Menghitung Expected Return dengan model sesuaian pasar (market adjusted model) yaitu dengan menghitung return pasar harian selama periode pengamatan dengan menggunakan rumus.

$$
R_{m t}=\left[\frac{I H S G_{t}-I H S G_{t-1}}{I H S G_{t-1}}\right]
$$

Keterangan:

$\mathrm{Rmt}=$ Return pasar pada periode $\dagger$ IHSG† = Indeks Harga Saham Gabungan pada periode $†$ IHSGt-1 = Indeks Harga Saham Gabungan pada periode t-1

3. Menghitung Abnormal Return:

$$
A R i, \dagger=R i, t-E[R i, t]
$$

Keterangan:

$\mathrm{ARi}, \mathrm{t}=$ return tak normal (abnormal return) saham i pada periode $\dagger$

$\mathrm{Ri}, \dagger \quad=$ return riil saham $\mathrm{i}$ periode $\dagger$

$\mathrm{E}[\mathrm{Ri}, \mathrm{t}]=$ return ekspektasi saham $\mathrm{i}$ periode $\dagger$

4. Menghitung Average Abnormal Return (rata-rata return tak normal):

$$
A A R_{t}=\frac{\sum A R_{t}}{n}
$$

Keterangan:

AARt = rata-rata abnormal return pada periode ke- $\dagger$

ARt = abnormal return saham pada periode peristiwa ke- $\dagger$

$\mathrm{n} \quad=$ jumlah sampel/jumlah emiten yang diamati

5. Menghitung actual trading volume activity: 
TVA $_{t}=\frac{\text { Jumlah saham emiten } i \text { yang diperdagan gkan pada hari ke }-t}{\text { Jumlah saham emiten } i \text { yang tercatat di BEI pada hari ke }-t}$

6. Menghitung expected trading volume activity atau volume perdagangan yang diharapkan menggunakan metode model sesuaian pasar (market adjusted model):

ETVA $_{t}=\frac{\text { Total volume perdaganga } n \text { saham semua emiten pada hari ke }-t}{\text { Total saham yang beredar di pasar pada hari ke }-t}$

7. Menghitung abnormal trading volume activity:

ATVAt = Actual TVAt - expected TVAt

ATVAt : volume perdagangan abnormal yang terjadi di periode ke- $\uparrow$

Actual TVAt: volume perdagangan yang terjadi pada hari ke-†

Expected TVAt :

volume

perdagangan yang diharapkan pada hari ke- $\dagger$

8. Melakukan uji- $\dagger$ untuk data average abnormal return harian selama periode pengamatan. Uji one sample t-test digunakan untuk melihat signifikansi average abnormal return selama periode pengamatan dari emiten-emiten yang diamati.

Langkah-langkah dalam uji- $\dagger$ adalah sebagai berikut:

a. Merumuskan hipotesis terhadap AARt

H0.1 : AARt $=0$ : tidak terdapat average abnormal return (AAR) yang signifikan di sekitar tanggal pengumuman dividen.

H0.2: AARt $\neq 0$ : terdapat average abnormal return (AAR) yang signifikan di sekitar tanggal pengumuman dividen.

b. Menentukan tingkat signifikansi (a) $=5 \%$

c. Melakukan pengujian AAR dengan uji one sample t-test dengan

persamaan:

$$
t=\frac{A A R_{t}}{S_{t} / \sqrt{n}}
$$

Keterangan:

St $=$ Standar deviasi AAR saham pada periode ke- $\uparrow$

$\mathrm{n}=$ Jumlah emiten yang diamati

Besarnya standar deviasi dihitung dengan rumus:

$S=\sqrt{S^{2}}$

$S^{2}=\frac{n \sum x_{i}^{2}-\left(\sum x_{i}\right)^{2}}{n-(n-1)}$

Keterangan:

S2 = varians sampel

$S$ = standar deviasi sampel

$\mathrm{xi}$ = besarnya data tiap sampel

$\mathrm{n}=$ jumlah sampel/jumlah emiten yang diamati

d. Kriteria pengujian:

$\mathrm{H} 0,1$ diterima apabila tvalue $\geqslant(a)$

$=5 \%$

$\mathrm{H} 0,2$ diterima apabila tvalue $<$ (a) $=5 \%$

9. Melakukan uji paired sample t-test untuk data average abnormal trading volume activity dengan tujuan melihat signifikansi volume abnormal return 
perdagangan saham selama periode pengamatan dari emiten-emiten yang diamati.

Langkah-langkah dalam uji paired sample t-test sebagai berikut:

a. Merumuskan hipotesis terhadap ATVAt

$\mathrm{H1}, 1: \mathrm{ATVAt}=0$ : terdapat

perbedaan abnormal trading volume activity yang tidak signifikan sebelum dan sesudah pengumuman dividen.

$\mathrm{H1}, 2$ : ATVAt $\neq 0$ : terdapat

perbedaan abnormal trading volume activity yang signifikan sebelum dan sesudah pengumuman dividen.

b. Menentukan tingkat signifikansi (a) $=5 \%$

c. Melakukan pengujian ATVA dengan uji paired sample t-test dengan

persamaan:

$t=\frac{A T V A}{S_{t} / \sqrt{n}}$

Keterangan:

St $=$ Standar deviasi ATVA saham pada periode ke- $\dagger$

$\mathrm{n}=$ Jumlah emiten yang diamati

Besarnya standar deviasi dihitung dengan rumus:

$S=\sqrt{S^{2}}$

$S^{2}=\frac{n \sum x_{i}^{2}-\left(\sum x_{i}\right)^{2}}{n-(n-1)}$

Keterangan:

S2 = varians sampel
$S=$ standar deviasi sampel

$\mathrm{xi}=$ besarnya data tiap sampel

$\mathrm{n}=$ jumlah sampel/jumlah emiten yang diamati

d. Kriteria pengujian:

H1.1 diterima apabila tvalue $\geqslant(a)$ $=5 \%$

H1.2 diterima apabila tvalue < (a) $=5 \%$

\section{HASIL DAN PEMBAHASAN}

Analisis Average Abnormal Return Pada

Pengamatan Harian pada Kelompok

\section{Dividen Meningkat}

Pengujian secara statistic dilakukan dengan bantuan program SPSS ver. 16 dan didapatkan hasil yang dirangkum pada table di bawah ini:

Tabel 1.

Pengujian Abnotmal Return one sample tTest pada Kelompok Dividen Meningkat

\begin{tabular}{|c|c|c|c|c|}
\hline \multirow{2}{*}{$\begin{array}{c}\text { Event } \\
\text { Windo } \\
\qquad w\end{array}$} & \multirow{2}{*}{$\begin{array}{c}\text { Average } \\
\text { Abnormal } \\
\text { Return }\end{array}$} & \multicolumn{2}{|c|}{ Test Value $=0$} & \multirow{2}{*}{$\begin{array}{c}\text { Keteranga } \\
n\end{array}$} \\
\hline & & $\begin{array}{l}\text { Sig. (2- } \\
\text { tailed) }\end{array}$ & $t$ & \\
\hline$t+10$ & 0.007000 & 0.386 & 0.911 & $\mathrm{H}_{0}$ diterima \\
\hline$t+9$ & -0.000620 & 0.864 & -0.177 & Ho diterima \\
\hline$t+8$ & -0.009300 & 0.395 & -0.894 & $\mathrm{H}_{0}$ diterima \\
\hline$t+7$ & -0.005610 & 0.196 & -1.395 & $\mathrm{H}_{0}$ diterima \\
\hline$t+6$ & 0.002650 & 0.599 & 0.545 & $\mathrm{H}_{0}$ diterima \\
\hline$t+5$ & -0.001750 & 0.686 & -0.418 & $\mathrm{H}_{0}$ diterima \\
\hline$t+4$ & -0.004120 & 0.291 & -1.122 & $\mathrm{H}_{0}$ diterima \\
\hline$t+3$ & -0.010180 & 0.106 & -1.797 & Ho diterima \\
\hline$t+2$ & 0.000250 & 0.957 & 0.055 & $\mathrm{H}_{0}$ diterima \\
\hline$t+1$ & 0.001130 & 0.833 & 0.217 & $\mathrm{H}_{0}$ diterima \\
\hline to & 0.006690 & 0.145 & 1.598 & $\mathrm{H}_{0}$ diterima \\
\hline$t-1$ & 0.005530 & 0.403 & 0.877 & $\mathrm{H}_{0}$ diterima \\
\hline$t-2$ & -0.004390 & 0.205 & -1.366 & $\mathrm{H}_{0}$ diterima \\
\hline$t-3$ & -0.000540 & 0.932 & -0.087 & Ho diterima \\
\hline$t-4$ & 0.012480 & 0.159 & 1.536 & $\mathrm{H}_{0}$ diterima \\
\hline$t-5$ & -0.004560 & 0.142 & -1.607 & $\mathrm{H}_{0}$ diterima \\
\hline$t-6$ & -0.004870 & 0.255 & -1.215 & Ho diterima \\
\hline$t-7$ & -0.014220 & 0.038 & -2.434 & $\mathrm{H}_{0}$ ditolak \\
\hline$t-8$ & -0.005490 & 0.296 & -1.108 & $\mathrm{H}_{0}$ diterima \\
\hline t-9 & -0.000620 & 0.942 & -0.075 & $\mathrm{H}_{0}$ diterima \\
\hline$t-10$ & 0.008860 & 0.077 & 1.995 & $\mathrm{H}_{0}$ diterima \\
\hline
\end{tabular}

Sumber: hasil penelitian, (diolah 2016)

Pada masa pengamatan selama 21 hari perdagangan, diketahui jika 
mayoritas data memiliki probabilitas yang lebih besar dari 0.05.Mayoritas data memiliki probabilitas lebih besar dari 0.05 . Maka, HO diterima dan $\mathrm{HI}$ ditolak. Hal ini menunjukkan bahwa terdapat abnormal return yang tidak signifikan di sekitar tanggal pengumuman dividen meningkat. Kesimpulan dari penjelasan ini adalah pasar tidak beraksi atas peristiwa pengumuman dividen meningkat yang dilakukan oleh emiten.

Analisis Average Abnormal Return Pada Pengamatan Harian pada Kelompok Dividen Menurun

Tabel 2.

Pengujian Abnotmal Return one sample tTest pada Kelompok Dividen Meningkat

\begin{tabular}{|c|c|c|c|c|}
\hline \multirow{2}{*}{$\begin{array}{l}\text { Event } \\
\text { Window }\end{array}$} & \multirow{2}{*}{$\begin{array}{l}\text { Average } \\
\text { Abnormal } \\
\text { Return }\end{array}$} & \multicolumn{2}{|c|}{ Test Value $=0$} & \multirow[b]{2}{*}{ Keterangan } \\
\hline & & $\begin{array}{l}\text { Sig. (2- } \\
\text { tailed) }\end{array}$ & $t$ & \\
\hline$t+10$ & 0.005929 & 0.306 & 1.066 & Ho diterima \\
\hline$t+9$ & -0.003564 & 0.304 & \begin{tabular}{|l|}
-1.070 \\
\end{tabular} & $\mathrm{H}_{0}$ diterima \\
\hline$t+8$ & -0.002843 & 0.580 & -0.567 & $\mathrm{H}_{0}$ diterima \\
\hline$t+7$ & -0.002750 & 0.570 & -0.583 & $\mathrm{H}_{0}$ diterima \\
\hline$t+6$ & 0.010914 & 0.073 & 1.954 & Ho diterima \\
\hline$t+5$ & 0.002521 & 0.671 & 0.435 & $\mathrm{H}_{0}$ diterima \\
\hline$t+4$ & -0.005764 & 0.331 & \begin{tabular}{|l|}
-1.011 \\
\end{tabular} & Ho diterima \\
\hline$t+3$ & 0.004957 & 0.462 & \begin{tabular}{|l|l|}
0.757 \\
\end{tabular} & Ho diterima \\
\hline$t+2$ & -0.007800 & 0.056 & \begin{tabular}{|l|}
-2.099 \\
\end{tabular} & $\mathrm{H}_{0}$ diterima \\
\hline$t+1$ & 0.002264 & 0.632 & \begin{tabular}{|l|}
0.491 \\
\end{tabular} & Ho diterima \\
\hline to & 0.006329 & 0.163 & 1.478 & $\mathrm{H}_{0}$ diterima \\
\hline$t-1$ & -0.007750 & 0.127 & -1.629 & $\mathrm{H}_{0}$ diterima \\
\hline$t-2$ & 0.000843 & 0.886 & \begin{tabular}{|l|}
0.146 \\
\end{tabular} & $\mathrm{H}_{0}$ diterima \\
\hline$t-3$ & -0.001157 & 0.764 & -0.306 & Ho diterima \\
\hline$t-4$ & 0.002179 & 0.591 & 0.551 & $\mathrm{H}_{0}$ diterima \\
\hline$t-5$ & 0.003800 & 0.263 & 1.169 & Ho diterima \\
\hline$t-6$ & 0.002250 & 0.618 & 0.510 & $\mathrm{H}_{0}$ diterima \\
\hline$t-7$ & 0.007114 & 0.308 & 1.061 & $\mathrm{H}_{0}$ diterima \\
\hline$t-8$ & -0.001886 & 0.598 & \begin{tabular}{|l|}
-0.540 \\
\end{tabular} & $\mathrm{H}_{0}$ diterima \\
\hline$t-9$ & 0.003900 & 0.474 & \begin{tabular}{|l|}
0.738 \\
\end{tabular} & $\mathrm{H}_{0}$ diterima \\
\hline$t-10$ & -0.003093 & 0.428 & -0.818 & $\mathrm{H}_{0}$ diterima \\
\hline
\end{tabular}

Sumber: hasil penelitian, (diolah 2016)

Selama periode pengamatan sepanjang 21 hari aktif perdagangan pasar modal semua data memiliki nilai probabilitas lebih dari 0.05, Maka $\mathrm{H}_{0}$ diterima dan $\mathrm{H}_{1}$ ditolak. Artinya, terdapat abnormal return yang tidak signifikan di sekitar peristiwa pengumuman dividen menurun oleh pasar.

Analisis Average Trading Volume Activity Pada Pengamatan Harian pada Kelompok Dividen Meningkat

Tabel 3.

Uji Statistik Paired t-Test Correlation Activity (AATVA) Kelompok Dividen Meningkat

\begin{tabular}{|l|l|l|}
\hline & $\begin{array}{l}\text { AATVA Sebelum } \\
\text { Pengumuman }\end{array}$ & $\begin{array}{l}\text { AATVA Setelah } \\
\text { Pengumuman }\end{array}$ \\
\hline Mean & 0.00009850 & 0.00045620 \\
\hline $\begin{array}{l}\text { Standar } \\
\text { Deviasi }\end{array}$ & 0.000280937 & 0.000523930 \\
\hline T & \multicolumn{2}{|c|}{-1.670} \\
\hline Df & \multicolumn{2}{|c|}{9.129} \\
\hline $\begin{array}{l}\text { Sig. (2- } \\
\text { tailed) }\end{array}$ & \multicolumn{2}{|c|}{0.} \\
\hline Keterangan & \multicolumn{2}{|c|}{ Tidak Signifikan } \\
\hline
\end{tabular}

Sumber: hasil penelitian, (diolah 2016)

Dari table 3, diketahui AATVA sebelum dan setelah perusahaan melakukan pengumuman mengalami peningkatan yang menunjukkan adanya perbedaan sebelum dan seudah pengumuman. Namun, dari hasil pengujian statistik dapat ditarik kesimpulan bahwa terdapat perbedaan rata-rata abnormal trading volume activity yang tidak signifikan sebelum dan setelah emiten melakukan pengumuman pembagian dividen yang meningkat. Maka HO diterima dan $\mathrm{Hl}$ ditolak.

Analisis Average Trading Volume Activity Pada Pengamatan Harian pada Kelompok Dividen Menurun

Tabel 4.

Uji Statistik Paired t-Test Correlation Activity (AATVA) Kelompok Dividen Menurun

\begin{tabular}{|l|l|l|}
\hline & $\begin{array}{l}\text { AATVA } \\
\text { Sebelum } \\
\text { Pengumuman }\end{array}$ & $\begin{array}{l}\text { AATVA } \\
\text { Setelah } \\
\text { Pengumuman }\end{array}$ \\
\hline Mean & 0.000123600 & 0.000014030 \\
\hline $\begin{array}{l}\text { Standar } \\
\text { Deviasi }\end{array}$ & 0.0001490055 & 0.0002382299 \\
\hline$T$ & \multicolumn{2}{|c|}{1.485} \\
\hline
\end{tabular}




\begin{tabular}{|l|l|l|}
\hline & $\begin{array}{l}\text { AATVA } \\
\text { Sebelum } \\
\text { Pengumuman }\end{array}$ & $\begin{array}{l}\text { AATVA } \\
\text { Setelah } \\
\text { Pengumuman }\end{array}$ \\
\hline df & \multicolumn{2}{|c|}{9} \\
\hline $\begin{array}{l}\text { Sig. (2- } \\
\text { tailed) }\end{array}$ & \multicolumn{2}{|c|}{0.172} \\
\hline Keterangan & \multicolumn{2}{|c|}{ Tidak Signifikan } \\
\hline
\end{tabular}

Pada tabel 4, Secara matemats, terjadi perubahan dimana rata-rata AATVA menurun setelah emiten mengumumkan pembagian dividen.

Tetapi, dari hasil pengujian perbedaan rata-rata abnormal trading volume activity kelompok saham perusahaan yang mengumumkan pembagian dividen menurun diperoleh $t=1.485$ dengan signifikansi sebesar 0.172 atau berada di atas 0.05. Hal ini menunjukkan bahwa ada perbedaan yang tidak signifikan pada rata-rata abnormal trading volume activity. Kesimpulannya, sebelum dan setelah pengumuman pembagian dividen menurun tidak terdapat reaksi perdagangan saham yang signifikan, maka $\mathrm{HO}$ diterima dan $\mathrm{HI}$ ditolak.

\section{Pembahasan}

Hasil penelitian menunjukkan tidak terdapat Average Abnormal Return (AAR) positif yang signifikan dan perbedaan Average Abnormal Trading Volume Activity (AATVA) positif yang signifikan sebelum dan sesudah pengumuman dividen pada perusahaan yang mengumumkan dividen meningkat. Artinya, pengumuman dividen meningkat tidak menimbulkan reaksi pada pasar.

Pengumuman dividen yang meningkat seharusnya dimaknai oleh investor sebagai sinyal baik karena peningkatan dividen bisa jadi bermakna perusahaan dalam keadaan likuiditas yang baik dan dapat mencerminkan earning prospect perusahaan ke depan. Reaksi yang diharapkan dari pengumuman dividen meningkat adalah reaksi positif di mana tidak ditemukan secara signifikan pada penelitian ini. Pasar seharusnya bereaksi secara cepat mengalami perubahan dan akhirnya terdapat abnormal return yang bisa didapat oleh investor, tetapi pada penelitian ini hanya keuntungan normal yang bisa didapatkan.

Adanya kebocoran informasi mengenai emiten yang akan membagikan dividen meningkat dinilai mengakibatkan informasi menyebar secara merata dan tidak menimbulkan gejolak harga yang positif dan berarti sehingga investor hanya dapat menikmati return normal.

Pada emiten yang mengumumkan dividen menurun, tidak ditemukan Average Abnormal Return (AAR) bernilai negatif yang signifikan dan tidak terdapat penurunan Average Abnormal Trading Volume Activity (AATVA) yang signifikan sebelum dan sesudah pengumuman. Hal ini berimplikasi bahwa tidak ada reaksi pasar yang ditimbulkan pada pengumuman dividen yang menurun. Pengumuman dividen menurun mengindikasikan bahwa perusahaan dalam keadaan likuiditas yang kurang baik sehingga akan direspon sebagai sinyal kurang baik oleh pada investor. 
Widodo, et al/Jurnal Ekonomi Syariah Teori dan Terapan Vol. 3 No. 2 Februari 2016: 85-98; REAKSI PASAR ATAS PENGUMUMAN DIVIDEN (STUDI PADA EMITEN YANG TERDAFTAR DI JAKARTA ISLAMIC INDEX)

Respon pasar yang biasa-biasa saja bisa jadi karena investor menganggap pengumuman dividen yang menurun belum tentu sebagai sinyal buruk mengenai perusahaan. Bisa jadi, penurunan dividen belum tentu mengindikasikan perusahaan kesulitan likuiditas namun meningkatkan laba ditahan dengan tujuan reinvestasi (Kartini, 2001).

Penemuan pada penelitian ini berhasil mengkonfirmasi penelitian yang dilakukan oleh Mulyono (2001) yang menemukan tidak ada reaksi pasar yang signifikan pada peristiwa pengumuman dividen meningkat maupun menurun. Penelitian yang dilakukan Zainafree (2005) juga mendapati reaksi pasar negatif yang tidak signifikan pada peristiwa pengumuman dividen yang menurun.

Hasil pada penelitian ini menunjukkan bahwa pada peristiwa pengumuman perubahan maupun menurun tidak tidak direaksi oleh pasar dibuktikan dengan tidak ada abnormal return yang signifikan. Hartono (2013:587) menyatakan bahwa tidak adanya abnormal return yang signifikan pada suatu peristiwa berimplikasi pada tidak ada kandungan informasi pada peristiwa tersebut. Implikasi dengan Hipotesis Pasar Efisien, penelitian ini menunjukkan bahwa pasar saham syariah di Indonesia belum efisien secara keputusan, Hartono (2013:590) menytakan bahwa tidak adanya abnormal return yang signifikan pada suatu peristiwa yang memiliki nilai ekonomis merupakan reaksi yang tidak benar sehingga secara keputusan, pasar tidak efisien.

Penelitian ini juga menunjukkan bahwa Jakarta Islamic Index (JII) sebagai proyeksi Pasar modal syariah di Indonesia belum dapat berjalan dengan efisien seperti yang telah diatur dalam syariah dimana pasar diharapkan mampu menyerap dan bereaksi atas suatu informasi yang bernilai ekonomis dengan cepat dan benar. Pasar seharusnya dapat dengan cepat merefleksikan informasiinformasi mengenai value dari sekuritas emiten.

\section{SIMPULAN}

1. Pengumuman dividen yang meningkat oleh emiten tidak direaksi positif oleh AAR. Hal ini tampak dari adanya AAR yang tidak signifikan di sekitar tanggal pengumuman dividen yang dilakukan oleh emiten terdaftar di Jakarta Islamic Index (JII). Mayoritas data yaitu sebanyak 20 dari 21 hari pengamatan memiliki nilai probabilitas lebih besar dari 0.05 .

2. Pengumuman dividen yang meningkat oleh emiten tidak direaksi positif oleh AATVA. Hasil penelitian terhadap average abnormal trading volume activity AATVA dengan uji statistik paired sample t-test menunjukkan adanya perbedaan yang tidak signifikan pada AATVA pada kelompok emiten terdaftar di Jakarta Islamic Index (JII) yang mengumumkan dividen meningkat sebelum dan sesudah pengumuman, 
Widodo, et al/Jurnal Ekonomi Syariah Teori dan Terapan Vol. 3 No. 2 Februari 2016: 85-98; REAKSI PASAR ATAS PENGUMUMAN DIVIDEN (STUDI PADA EMITEN YANG TERDAFTAR DI JAKARTA ISLAMIC INDEX)

dengan nilai probabilitas sebesar 0.129 .

3. Pengumuman dividen yang menurun oleh emiten tidak direaksi negatif oleh AAR. Hasil penelitian menunjukkan adanya AAR yang tidak signifikan di sekitar tanggal pengumuman dividen menurun yang dilakukan oleh emiten terdaftar di Jakarta Islamic Index (JII). Semua data pengamatan, yaitu pada 21 hari perdagangan aktf menunjukkan nilai probabilitas diatas 0.05 .

4. Pengumuman dividen yang menurun oleh emiten tidak direaksi negatif oleh average AATVA. Hasil penelitian terhadap AATVA dengan uji statistik paired sample t-test menunjukkan adanya perbedaan yang tidak signifikan pada AATVA sebelum dan sesudah pengumuman dividen menurun pada kelompok emiten terdaftar di Jakarta Islamic Index (JII) yang mengumumkan dividen menurun, dengan nilai probabilitas sebesar 0.129 .

Dari kesimpulan di atas, dapat di rangkum bahwa peristiwa pengumuman pembagian dividen yang meningkat maupun menurun tidak direspon oleh pasar. Selain itu penelitian ini juga menunjukkan bahwa pasar modal syariah di Indonesia masih belum efisien secara keputusan.

\section{DAFTAR PUSTAKA}

Agriani, Novia. 2011. Analisis Reaksi Pasar Sebelum dan Sesudah Adanya Pengumuman Dividen (Studi Empiris Pada Perusahaan yang Go Public). Universitas Negeri Lampung.

Bhattacharya, S. 1979. Imperfect information, dividend policy, and "The Bird in The Hand" Fallacy. Bell Journal of Economics, Vol. 10, No. 1, hal. 259270.

Dariyus, 2012. Apakah Kinerja dan Risiko Reksadana Syariah Lebih Baik Dibandingkan dengan Reksadana Konvensional. Jurnal Orasi Bisnis, Edisi ke-VIII, November 2012 ISSN: 2085-1375.

Hartono, Jogyanto. 2013. Teori Portofolio dan Analisis Investasi. Edisi Kedelapan. Yogyakarta: BPFE.

Krichene, Noureddine. 2013. Islamic Capital Market Theory and Practice. Singapura: John Wiley \& Sons.

Kustodian Sentral Efek Indonesia. Publikasi Pengumuman Corporate Action. 2014, (Daring), (http://web.ksei.co.id/corporat e_action_schedule/cash_dividend, diakses selama periode penelitian).

Mirdah, Andi dan Agus Solikin. 2010. Analisis Dampak Pengumuman Dividen Terhadap Reaksi Pasar (Studi Empiris pada Bursa Efek Jakarta periode Tahun 2008). Jurnal Penelitian Universitas Jambi Seri Humaniora, Volume 12, Nomor 2, Hal. 01-08 Juli - Desember 2010. ISSN 0852-8349. Jambi: Lembaga Penelitian Universitas Jambi.

Mulyati, Sri. 2003. Reaksi Harga Saham terhadap Perubahan Dividen Tunai dan 
Dividen Yield di bursa Efek Jakarta. Jurnal Siasat Bisnis, Halaman 233-249 JSB No. 8 Vol. 2 Desember 2003.

Mulyono. 2001. Pengaruh Pengumuman Dividen terhadap Harga Saham di Bursa Efek Surabaya (BES). Thesis Fakultas Ekonomi dan Bisnis Universitas Airlangga.

Nawawi, Ismail. 2012. Fiqih Muamalah Klasik dan Kontemporer: Hukum Perjanjian, Ekonomi, Bisnis, dan Sosial. Bogor: Ghalia Indonesia.

Obaidullah, Mohammed. 2007. Teaching Corporate Finance From an Islamic Prespective. Jeddah: Islamic Economics Research Centre King Abdulaziz University.

Ross, Stephen A., Randolph W. Westerfield, and Bradford D. Jordan. 2008. Corporate Finance Fundamentals 8th edition. New York: McGraw-Hill.

Wahyuni, Putu Ayu Sri dan I Made Sukartha. 2012. Reaksi Pasar terhadap Pengumuman Dividen Perusahaan yang Termasuk Kategori LQ45. Jurnal Universitas Udayana.

Zainafree, Golda. 2005. Reaksi Harga Saham terhadap Pengumuman Pembayaran Dividen Tunai di Bursa Efek Jakarta. Thesis Program Pasca Sarjana Universitas Diponegoro. 